\title{
\|ARTYKULY
}

PRZEGLAD SEJMOWY

nr 3(158)/2020, s. 9-28; https://doi.org/10.31268/PS.2020.32

PAWEŁ BUCOŃ*

\section{Konstytucyjne prawo dziecka do opieki i pomocy wladz publicznych}

Artykuł poświęcony jest konstytucyjnemu prawu dziecka do opieki i pomocy władz publicznych (art. 72 Konstytucji Rzeczypospolitej Polskiej z 1997 r.). Autor dokonuje analizy następujących elementów składających się na to prawo: prawo dziecka do ochrony przed przemocą, okrucieństwem, wyzyskiem i demoralizacją, prawo do opieki i pomocy władz publicznych w sytuacji pozbawienia opieki rodzicielskiej oraz prawo dziecka do wysłuchania i w miarę możliwości uwzględnienia jego zdania przez organy władzy publicznej oraz osoby odpowiedzialne za dziecko w toku ustalania praw dziecka. W artykule zostało omówione również pojęcie „dziecka” na tle przepisów konstytucyjnych oraz rozbieżne z nim pojmowanie „dziecka” w kodeksie cywilnym oraz kodeksie rodzinnym i opiekuńczym.

SŁowa KLuczowe: Konstytucja Rzeczypospolitej Polskiej, prawo cywilne, prawa dziecka, prawo rodzinne

\section{The constitutional right of a child to care and help of public authorities}

The article is devoted to the constitutional right of a child to care and help of public authorities (Article 72 of the Constitution of the Republic of Poland of 1997). The author analyses the following elements that make up this right: the right of a child to protection against violence, cruelty, exploitation and demoralisation, the right to care and help of public authorities in the event of deprivation of parental care and the right of a child to be heard and have his/her opinion taken into account, where possible, by public authorities and persons responsible for the child in the course of determining a child's rights. The article also discusses the problem of determining the term "child" against the background of constitutional provisions and the divergent conception of a "child" in the Civil Code and the Family and Guardianship Code.

KeY words: Constitution of the Republic of Poland, civil law, children's rights, family law

* Dr Paweł Bucoń, Katolicki Uniwersytet Lubelski Jana Pawła II, sędzia Sądu Rejonowego Lublin-Wschód w Lublinie z siedzibą w Świdniku, pawelbucon@kul.lublin.pl, https://orcid.org/0000-0002-4413-2588 


\section{Wprowadzenie}

Konstytucja Rzeczypospolitej Polskiej z dnia 2 kwietnia 1997 r. ${ }^{1}$ gwarantuje poszanowanie praw rodziny i dziecka². Niezależnie od szczegółowych regulacji Rozdziału II (w szczególności art. 48, art. 71 i będącego przedmiotem analizy w niniejszym opracowaniu art. 72) ochrona rodziny i dziecka ma rangę zasady konstytucyjnej. Wniosek taki wypływa z art. 18 konstytucji: „Małżeństwo jako związek kobiety i mężczyzny, rodzina, macierzyństwo i rodzicielstwo znajdują się pod ochroną i opieką Rzeczypospolitej Polskiej”. Z regulacji przyjętej przez ustrojodawcę wynika, że prawa rodziny i jej członków są ze sobą powiązane i tworzą jednolitą całość. Oznacza to, że pierwszym i bez wątpienia istotnym prawem dziecka jest prawo do życia i wychowania przez naturalnych rodziców, w pełnej rodzinie, spełniającej wszystkie podstawowe funkcje przypisane jej jako podstawowej komórce społecznej ${ }^{3}$. Ustrojodawca wyraża również troskę o należyte zabezpieczenie praw dziecka przez zagwarantowanie prawa do nauki (art. 70) $)^{4}$, ustanowienie zakazu stałego zatrudniania dzieci do lat 16 (art. 65 ust. 3$)^{5}$ oraz prawa do szczególnej opieki zdrowotnej (art. 68 ust. 3).

Jednak w sytuacji, w której rodzina jako naturalne środowisko funkcjonowania dziecka nie spełnia swoich podstawowych zadań, powinna nastąpić interwencja władz publicznych. Ma ona doprowadzić w pierwszej kolejności do udzielenia pomocy rodzinom dysfunkcyjnym. Dlatego też ustrojodawca nakłada na władze publiczne obowiązek udzielania „szczególnej pomocy” rodzinom znajdującym się w trudnej sytuacji materialnej i społecznej, zwłaszcza wielodzietnym i niepełnym (art. 71 ust. 1 konstytucji). Specyficzną formą realizacji owego zadania jest sformułowany w art. $100 \S 1$ kodeksu rodzinnego i opiekuńczego [dalej: k.r.o.] $]^{6}$ obowiązek sądu opiekuńczego i innych organów władzy publicznej udzielania pomocy rodzicom, jeżeli jest ona potrzebna do należytego wykonywania władzy rodzicielskiej.

Sytuacja dziecka może wymagać zapewnienia ochrony i pomocy nie tyle całej rodzinie, co samemu dziecku, niezależnie od możliwości ubiegania się przez rodziny znajdujące się w trudnej sytuacji o udzielenie pomocy ze strony władz publicznych. Dlatego też na tle przepisów konstytucyjnych, a zwłaszcza art. 72, możliwe jest skonstruowanie prawa dziecka do opieki i pomocy ze strony władz publicznych. W moim przekonaniu stanowi ono istotną część realizacji zadań państwa w obszarze zapewnienia

1 Dz.U. z 1997 r. nr 78, poz. 483, ze zm.

2 Treść przepisów konstytucyjnych w dużej mierze została zdeterminowana faktem ratyfikowania przez RP Konwencji o prawach dziecka przyjętej przez Zgromadzenie Ogólne ONZ 20 listopada 1989 r., Dz.U. z 1991 r. nr 120, poz. 526.

3 Prawu temu odpowiada wyrażone explicite w art. 48 ust. 1 konstytucji prawo rodziców do wychowania dzieci zgodnie z własnymi przekonaniami, przy uwzględnieniu stopnia dojrzałości dziecka, a także wolności jego sumienia i wyznania oraz jego przekonań.

4 Jednocześnie ustanowiony został we wskazanym przepisie obowiązek nauki do ukończenia 18. roku życia w sposób określony przepisami ustawy.

5 Formy i charakter dopuszczalnego zatrudniania dzieci określa ustawa.

${ }^{6}$ Ustawa z dnia 25 lutego 1964 r. — Kodeks rodzinny i opiekuńczy, tekst jedn. Dz.U. z 2017 r. poz. 682 , ze zm. 
praw dziecka (art. 72 ust. 1 zd. pierwsze konstytucji). Wychodzę z założenia, że na konstytucyjne prawo dziecka do opieki i pomocy ze strony władz publicznych składa się: 1) prawo do ochrony przed przemocą, okrucieństwem, wyzyskiem i demoralizacją (art. 72 ust. 1 zd. drugie konstytucji); 2) prawo do opieki i pomocy władz publicznych w sytuacji pozbawienia opieki rodzicielskiej (art. 72 ust. 2 konstytucji); 3) prawo do wysłuchania i formułowania swojego zdania przed organami władzy publicznej (art. 72 ust. 3 konstytucji). Nie stanowi natomiast części prawa do opieki i pomocy ze strony władz publicznych możliwość poszukiwania interwencji władz publicznych w proces wychowania dziecka, w konstytucji gwarantuje się bowiem prawo rodziców do wychowania dziecka zgodnie z własnymi przekonaniami (art. 48 ust. 1 zd. pierwsze), jak również prawo do ochrony życia prywatnego i rodzinnego (art. 47). Co prawda gwarancje konstytucyjne obejmują także wolność decydowania o swoim życiu osobistym (art. 47 in fine) oraz uwzględnienie kryteriów, jakim musi odpowiadać proces wychowania dziecka (stopnia dojrzałości dziecka, wolności jego sumienia i wyznania oraz jego przekonań), niemniej wiążą się one z osiągnięciem przez dziecko określonego stopnia dojrzałości, pozwalającego na formułowanie poglądów na temat aspektów procesu wychowania i nie powinny wiązać się z interwencją władz publicznych w relacje między rodzicami a dzieckiem, chyba że zachodzą szczególne przesłanki uzasadniające taką interwencję (np. konieczność ochrony zdrowia dziecka). Prawo do opieki i pomocy ze strony władz publicznych nie jest bowiem równoznaczne z możliwością ingerencji władz publicznych w proces wychowania dziecka.

Stosownie do poczynionych założeń w przedmiocie istoty konstytucyjnego prawa dziecka do opieki i pomocy władz publicznych w niniejszym opracowaniu analizie zostały poddane następujące kwestie: dziecko jako podmiot konstytucyjnych praw i wolności, prawo dziecka do ochrony przed przemocą, okrucieństwem, wyzyskiem i demoralizacją, prawo do opieki i pomocy władz publicznych w sytuacji pozbawienia opieki rodzicielskiej oraz prawo dziecka do wysłuchania i w miarę możliwości uwzględnienia jego zdania przez organy władzy publicznej oraz osoby odpowiedzialne za dziecko w toku ustalania praw dziecka.

\section{Dziecko jako podmiot konstytucyjnych praw i wolności}

$Z$ art. 18 konstytucji wynika, że podstawą życia rodzinnego chronionego przez dalsze postanowienia konstytucji jest małżeństwo rozumiane jako związek kobiety i mężczyzny. Stanowi ono podstawę rodziny, w ramach której gwarancjami ustrojodawcy objęte są macierzyństwo i rodzicielstwo (rozumiane jako ojcostwo ${ }^{7}$ ), a w dalszej kolejności

7 Wniosek taki wynika z faktu, że w komentowanym przepisie został użyty termin „macierzyństwo” (niezależnie od „rodzicielstwa”). Inny kierunek interpretacji może wskazywać, że rodzicielstwo obejmuje oprócz rodziców naturalnych również innych opiekunów prawnych dziecka (w razie ustania opieki rodzicielskiej), a w szczególności rodziców zastępczych. 
prawa dziecka jako szczególnego, ze względu na swą niedojrzałość, podmiotu konstytucyjnych praw i wolności ${ }^{8}$.

Analiza przepisów konstytucyjnych prowadzi do wniosku, że dobro rodziny, której podstawę stanowi małżeństwo, jest szczególnie istotną wartością konstytucyjną. Rodzina naturalna jest wspólnotą osób połączonych ścisłymi i trwałymi relacjami, o określonej strukturze i celach oraz — jak już wspomniano - spełniającą wiele doniosłych funkcji ${ }^{9}$. W takiej rodzinie może być urzeczywistniana konstytucyjna zasada dobra dziecka ${ }^{10}$. Ustrojodawca gwarantuje dziecku odpowiedni proces wychowania z uwzględnieniem stopnia jego dojrzałości, a także wolności sumienia i wyznania oraz jego przekonań (art. 48 ust. 1 konstytucji), przygotowujący je do pełnienia po osiągnięciu pełnoletności przypisanych ról społecznych. Dlatego też państwo obowiązane jest w swojej polityce społecznej i gospodarczej uwzględniać dobro rodziny, a w razie występowania niedających się przezwyciężyć problemów rodzina może liczyć na pomoc władz publicznych (art. 71 ust. 1 konstytucji).

$\mathrm{Z}$ owych wstępnych ustaleń nie wynika, aby macierzyństwo i rodzicielstwo, nie mówiąc już o prawach dziecka, funkcjonujące poza ramami tradycyjnej rodziny było objęte mniejszym zakresem gwarancji konstytucyjnych ${ }^{11}$. W art. 71 ust. 1 zd. pierwsze konstytucji państwo w swojej polityce społecznej i gospodarczej uwzględnia dobro rodziny niezależnie od tego, czy podstawę rodziny tworzy małżeństwo rozumiane jako związek kobiety i mężczyzny, czy też związek nieformalny w jakiejkolwiek postaci ${ }^{12}$. Co więcej, w art. 71 ust. 1 zd. drugie ustrojodawca przyznaje prawo do szczególnej pomocy ze strony władz publicznych rodzinom znajdującym się w trudnej sytuacji materialnej i społecznej, zwłaszcza wielodzietnym i niepełnym. Ostatnie z użytych sfor-

${ }^{8}$ Art. 18 konstytucji nie można jednak interpretować w taki sposób, że tylko macierzyństwo realizowane w ramach rodziny objęte jest gwarancjami konstytucyjnymi. Co innego zresztą wynika wprost $\mathrm{z}$ dalszych przepisów ustawy zasadniczej (w szczególności art. 71 ust. 2).

${ }^{9}$ M. Dobrowolski, Status prawny rodziny w świetle nowej Konstytucji Rzeczypospolitej Polskiej, „Przegląd Sejmowy” 1999, nr 4(33), s. 24.

${ }_{10}$ TK trafnie sformułował związek dobra dziecka $\mathrm{z}$ procesem wychowania $\mathrm{w}$ rodzinie $\mathrm{w}$ wyroku z 28 kwietnia 2003 r. (sygn. akt K 18/02, OTK 2003/4A/32): „Najpełniejsza realizacja zasady dobra dziecka dokonywać się może poprzez zapewnienie możliwości jego wychowania w rodzinie, przede wszystkim w rodzinie naturalnej, a więc poprzez pieczę rodzicielską sprawowaną przez osoby związane z dzieckiem więzią biologiczną". Zasada dobra dziecka, kluczowa dla określenia jego sytuacji prawnej, wymaga odrębnych studiów. Spośród aktualnej literatury przedmiotu vide m.in. M. Ożóg, Dobro dziecka, czyli poszanowanie jego podmiotowości prawnej w świetle wybranych przepisów prawa polskiego, [w:] Dobro dziecka. Perspektywa pedagogiczna i prawna, red. E. Włodek, Z. Solak, T. Gurdak, Kraków 2017, s. 79 i n.; L. Zacharko, B. Wartenberg-Kempka, Dobro dziecka jako wartość najwyższa w prawie administracyjnym, [w:] Aksjologia prawa administracyjnego, t. 1, red. J. Zimmermann, Warszawa 2017, s. 281 i n.

${ }^{11}$ Confer M. Dobrowolski, op. cit., s. 26: „Konstytucyjną ochronę, stosownie do art. 18, uzyskuje każde macierzyństwo, niezależnie od stanu cywilnego matki, oraz każde małżeństwo, niezależnie od posiadania lub nieposiadania dzieci. Ochronie podlega także każda rodzina, zarówno pełna, jak i niepełna oraz bezdzietna".

${ }^{12}$ Związku nieformalnego na tle przepisów konstytucyjnych nie należy ograniczać do pojęcia konkubinatu w prawie rodzinnym. Inną kwestią jest dopuszczalność prawnej formalizacji owych związków, która jednak nie ma znaczenia z punktu widzenia ochrony praw wychowującego się w nim dziecka. 
mułowań (rodziny „niepełne”) daje — w moim przekonaniu — prawo do ubiegania się o pomoc władz publicznych ze strony osób tworzących różnego rodzaju związki nieformalne, zwłaszcza jeżeli celem pomocy ma być zapewnienie odpowiedniego procesu wychowania dziecka w takiej rodzinie lub zapewnienie mu odpowiedniego bytu socjalnego. W żadnym wypadku nie można ograniczać pojęcia rodzin „niepełnych” w rozumieniu konstytucyjnym do sytuacji, w której dochodzi do rozpadu związku małżeńskiego tworzącego dotychczas podstawę rodziny.

Z powyższej analizy wynika, że rodzicami w rozumieniu konstytucyjnym mogą być nie tylko osoby tworzące małżeństwo rozumiane jako związek kobiety i mężczyzny, ale również tworzące jakikolwiek związek nieformalny, którego owocem jest dziecko. Należy uznać lege non distinguente, że również tego typu macierzyństwo i rodzicielstwo znajduje się pod ochroną i opieką RP (art. 18). Podobnie matka przed urodzeniem i po urodzeniu dziecka ma prawo do szczególnej pomocy władz publicznych (art. 71 ust. 2) niezależnie od tego, czy dziecko pochodzi z zawartego przez nią małżeństwa. Według identycznego założenia należy interpretować prawo kobiety ciężarnej do szczególnej opieki zdrowotnej (art. 68 ust. 3).

Prawa dziecka podlegają ochronie konstytucyjnej niezależnie od tego, czy dziecko pochodzi z małżeństwa, czy też z jakiegokolwiek innego związku. Rzecz tę ustrojodawca uważa na tyle za oczywistą, że nie ma w konstytucji szczególnego przepisu gwarantującego równą ochronę praw dziecka ${ }^{13}$. Dlatego należy się odwołać do art. 32 konstytucji, który gwarantuje wszystkim równość wobec prawa, prawo do równego traktowania przez władze publiczne oraz zakaz dyskryminacji z jakiejkolwiek przyczyny (a więc również z racji urodzenia się z rodziców niebędących małżeństwem).

Konstytucja nie zawiera definicji legalnej dziecka. Kluczowe znaczenie ma pod tym względem art. 65 ust. 3 konstytucji zakazujący stałego zatrudniania dzieci do lat 16 . Wynika z niego, że ustrojodawca za dziecko uznaje również osobę, która ukończyła 16. rok życia. Z pewnością status dziecka traci osoba wraz z ukończeniem 18. roku życia, ponieważ w tym dniu uzyskuje możliwość realizacji praw wyborczych (art. 62 ust. 1) ${ }^{14}$. Należy uznać, że dzieckiem w rozumieniu konstytucyjnym jest każda osoba, która nie ukończyła 18 lat, bez względu na to, czy pozostaje pod władzą rodzicielską ${ }^{15}$.

Z przepisami konstytucyjnymi określającymi pojęcie „dziecka” pozostają w wyraźnej dysharmonii przepisy prawa cywilnego i prawa rodzinnego. Należy wskazać,

${ }^{13} \mathrm{~W}$ szczególności należy podkreślić, że wynikający z art. 72 ust. 1 zd. pierwsze konstytucji obowiązek zapewnienia ochrony praw dziecka dotyczy wszystkich dzieci, bez względu na to, przez kogo i w jakich warunkach są wychowywane.

14 Confer P. Sarnecki, komentarz do art. 48, [w:] Konstytucja Rzeczypospolitej Polskiej. t. II: Komentarz do art. 30-86, red. L. Garlicki, M. Zubik, Warszawa 2016, s. 257-258; W. Borysiak, komentarz do art. 72, [w:] Konstytucja RP, t. I: Komentarz do art. 1-86, red. M. Safjan, L. Bosek, Warszawa 2016, s. $1659-1660$.

15 Przedstawiono podstawowe argumenty na rzecz tezy, że dzieckiem w rozumieniu Konstytucji RP jest każdy człowiek poniżej 18. roku życia. Kwestia określenia dziecka jako podmiotu konstytucyjnych praw i wolności, zwłaszcza w kontekście odbiegających od unormowań ustawy zasadniczej przepisów prawa prywatnego, będzie przedmiotem odrębnego opracowania przez autora niniejszego artykułu. 
że kodeks rodzinny i opiekuńczy upatruje istotę pojęcia „dziecka” w kategoriach niepełnoletności i pozostawania pod władzą rodzicielską. Zgodnie z art. 92 k.r.o. dziecko pozostaje aż do uzyskania pełnoletności pod władzą rodzicielską ${ }^{16}$. Dziecko stanowi zatem jedną ze stron stosunku prawnego władzy rodzicielskiej ${ }^{17}$. Tymczasem, jak już wskazano, z punktu widzenia konstytucji pozostawanie pod władzą rodzicielską nie ma znaczenia, ponieważ dzieckiem jest każda osoba, która nie ukończyła 18. roku życia. Ustrojodawca nie operuje pojęciami „pełnoletności” i „niepełnoletności” (względnie „małoletniości”) ${ }^{18}$. Tym bardziej dla unormowań konstytucyjnych określających pojęcie „dziecka” nie mają znaczenia przepisy kodeksu rodzinnego i opiekuńczego czy też kodeksu cywilnego.

Różnica w pojmowaniu dziecka w przepisach konstytucyjnych i kodeksowych jest tym istotniejsza, że prawo cywilne dopuszcza możliwość osiągnięcia pełnoletności przez osobę, która nie ukończyła 18 . roku życia ${ }^{19}$, z czym wiąże się uzyskanie pełnej zdolności do czynności prawnych ${ }^{20}$. Dotyczy to kobiety, która po ukończeniu 16. roku życia (a przed ukończeniem lat 18) zawrze za zgodą sądu związek małżeński ${ }^{21}$. Należy podkreślić, że konstytucyjny status takiej osoby nie ulega zmianie, tzn. aż do ukończenia 18. roku życia pozostaje ona dzieckiem w rozumieniu przepisów ustawy zasadniczej. Przez fakt uzyskania pełnej zdolności do czynności prawnej nie traci zatem możliwości korzystania z praw dziecka zagwarantowanych przez konstytucję. Może podjąć stałe zatrudnienie (art. 65 ust. 3), lecz fakt ten nie wynika z racji uzyskania pełnej zdolności do czynności prawnych, lecz ukończenia 16. roku życia. Nadal wobec takiej kobiety ma zastosowanie konstytucyjny obowiązek pobierania nauki aż do ukończenia 18 lat (art. 70 ust. 1 zd. drugie). Mimo że z punktu widzenia prawa rodzinnego kobieta taka nie jest dzieckiem, gdyż nie pozostaje już pod władzą rodzicielską, to z kon-

${ }^{16} \mathrm{~W}$ art. 10 ust. 1 k.c. (tekst jedn. Dz.U. z 2018 r. poz. 1025 , ze zm.) pełnoletnim jest ten, kto ukończył lat 18 .

17 E. Markowska-Gos, Realizacja praw dziecka we współczesnej rodzinie - wybrane aspekty socjologiczno-prawne, [w:] Prawa dziecka. Wybrane aspekty, red. I. Marczykowska, E. Markowska-Gos, A. Solak, W. Walc, Rzeszów 2006, s. 158.

${ }^{18}$ Inną definicję dziecka zawiera Konwencja o prawach dziecka. Zgodnie z jej art. 1 dzieckiem jest każda istota ludzka w wieku poniżej 18 lat, chyba że zgodnie z prawem odnoszącym się do dziecka uzyska ono wcześniej pełnoletność.

${ }^{19}$ Na podstawie art. 10 ust. 2 k.c. małoletni uzyskuje pełnoletność przez zawarcie małżeństwa i nie traci jej w razie unieważnienia małżeństwa.

${ }^{20}$ Zgodnie z art. 11 k.c. pełną zdolność do czynności prawnych nabywa się z chwilą uzyskania pełnoletności.

${ }^{21}$ Zgodnie $\mathrm{z}$ art. $10 \S 1 \mathrm{zd}$. drugie k.r.o. z ważnych powodów sąd opiekuńczy może zezwolić na zawarcie małżeństwa kobiecie, która ukończyła lat 16, a z okoliczności wynika, że zawarcie małżeństwa będzie zgodne z dobrem założonej rodziny. Powodem uzasadniającym zgodę sądu jest w praktyce najczęściej zajście w ciążę przez kobietę, która ubiega się o zezwolenie. Przepisy obowiązującego prawa nie przewidują natomiast żadnej możliwości zawarcia związku małżeńskiego przez mężczyznę, który nie ukończył 18. roku życia, z czym wiąże się brak możliwości wcześniejszego osiągnięcia pełnoletności. Pojawia się w związku z tym pytanie o zgodność rozwiązań kodeksowych z konstytucyjną zasadą równości kobiet i mężczyzn m.in. w życiu rodzinnym (art. 33 konstytucji). Vide M. Domański, Względne zakazy matżeńskie, Warszawa 2013, s. 141 i n. 
stytucyjnego punktu widzenia zachowuje prawo do opieki rodzicielskiej. Jeżeli zatem rodzice odmawiają takiej kobiecie pomocy i wsparcia czy jakiejkolwiek innej formy opieki, powstaje po jej stronie prawo do opieki i pomocy władz publicznych (art. 72 ust. 2 konstytucji).

Dziecko, inaczej niż rodzina, posiada podmiotowość prawną i z tego tytułu jest podmiotem wszystkich konstytucyjnie gwarantowanych praw i wolności jednostki ${ }^{22}$, chyba że co innego wynika z postanowień ustawy zasadniczej (jak chociażby w przypadku praw wyborczych). Ze względu na swą niedojrzałość nie może bowiem korzystać samodzielnie ze wszystkich praw i wolności ${ }^{23}$. Oprócz tego dziecko jest podmiotem praw i wolności, które ustrojodawca odnosi wyłącznie do niego. Inną sprawą jest, w jakim zakresie dziecko jako osoba niedojrzała jest w stanie samodzielnie realizować owe prawa i wolności. Dlatego też Trybunał Konstytucyjny sformułował nakaz zapewnienia ochrony interesów małoletniego, który w praktyce może jej dochodzić w ograniczonym zakresie $^{24}$. Ze względu na niedojrzałość dziecko nie jest w stanie skutecznie zapewnić ochrony swoich interesów i z tego tytułu musi liczyć w przypadku braku rodziców na wsparcie ze strony organów władzy publicznej ${ }^{25}$. Uznając ów stan rzeczy, ustrojodawca sformułował przepisy stanowiące podstawę prawa dziecka do opieki i pomocy ze strony władz publicznych.

Prawa dziecka są prawami człowieka. Zgodnie z art. 5 konstytucji Rzeczpospolita Polska zapewnia wolności i prawa człowieka i obywatela, stąd też podkreślenie przez ustrojodawcę w art. 72 ust. 1 zd. pierwsze, że Rzeczpospolita Polska zapewnia ochronę praw dziecka, mogłoby się wydawać tautologią ${ }^{26}$. Należy jednak uznać, że ustrojodawca podkreśla w ten sposób znaczenie poszanowania praw dziecka i uwzględnienia zasady dobra dziecka w polityce państwa. Celem ochrony zapewnionej w art. 72 ust. 1 konstytucji jest dobro dziecka²7. Mimo iż pojęcie to nie ma w polskim prawie sprecyzowanego znaczenia $^{28}$, to posiada rangę zasady konstytucyjnej, wynika bowiem logicznie z zasady dobra rodziny wyrażonej expressis verbis $\mathrm{w}$ art. 71 ust. $1 \mathrm{zd}$. pierwsze konstytucji ${ }^{29}$. Zasada dobra dziecka odgrywa kluczową rolę w procesie stosowania prawa, a zwłaszcza

${ }^{22}$ Confer W. Borysiak, komentarz do art. 72..., s. 1659; H. Babiuch, Konstytucyjne prawa rodziców $w$ zakresie wychowania dziecka, [w:] Realizacja i ochrona konstytucyjnych wolności i praw jednostki w polskim porządku prawnym, red. M. Jabłoński, Wrocław 2014, s. 181; M. Andrzejczak-Świątek, Ochrona praw dziecka w sytuacjach nadzwyczajnych, Warszawa 2016, s. 35; H. Bzdak, Prawo dziecka do życia i godnego wychowania - uwarunkowania prawne, religijne i społeczne, Szczecin 2000, s. 24.

23 B. Banaszak, Konstytucja Rzeczypospolitej Polskiej. Komentarz, Warszawa 2012, s. 429.

24 Vide W. Borysiak, komentarz do art. $72 \ldots$, s. 1659 i tam przywołane orzecznictwo TK.

25 B. Banaszak, op. cit., s. 425; confer wyrok TK z 28 kwietnia 2003 r. ...

${ }^{26}$ Confer A. Mączyński, Konstytucyjne podstawy prawa rodzinnego, [w:] Państwo prawa i prawo karne. Księga jubileuszowa Profesora Andrzeja Zolla, t. 1, red. P. Kardas, T. Sroka, W. Wróbel, Warszawa 2012, s. 766.

27 B. Banaszak, op. cit., s. 426.

28 M. Sokołowski, Dobro dziecka w prawie rodzinnym Unii Europejskiej. Aspekt formalnoprawny, [w:] Prawa dziecka w prawie międzynarodowym, red. E. Karska, Warszawa 2014, s. 95.

${ }^{29}$ Confer L. Garlicki, M. Derlatka, komentarz do art. 72, [w:] Konstytucja Rzeczypospolitej Polskiej, t. II: Komentarz do art. 30-86, red. L. Garlicki, M. Zubik, Warszawa 2016, s. 780. 
określania sytuacji prawnej dziecka przez organy władzy publicznej ${ }^{30}$. Stanowi również nadrzędną zasadę prawa rodzinnego, determinującą wszelkie relacje między rodzicami i dziećmi ${ }^{31}$. Jak stanowi art. $95 \S 3$ k.r.o., władza rodzicielska powinna być wykonywana tak, jak tego wymaga dobro dziecka i interes społeczny.

\section{Prawo dziecka do ochrony przed przemocą, okrucieństwem, wyzyskiem i demoralizacją}

Na podstawie przepisów konstytucyjnych można skonstruować prawo dziecka do odpowiedniego wychowania przez rodziców. Konstytucja RP nie nakłada na rodziców expressis verbis obowiązku troski o dziecko i zapewnienia mu należytego wychowania, niemniej wynika on implicite $\mathrm{z}$ art. 18, art. 48 , art. 71 i art. 72 konstytucji ${ }^{32}$. Rodzice są w pierwszej kolejności osobami odpowiedzialnymi za dziecko w rozumieniu art. 72 ust. 3 konstytucji. Już choćby z racji unormowań tego przepisu na rodzicach spoczywają określone obowiązki. Natomiast $\mathrm{z}$ art. 48 ust. 1 zd. drugie konstytucji wynika konieczność uwzględniania stopnia dojrzałości dziecka (jak również wolności jego sumienia i wyznania oraz przekonań) w procesie wychowawczym ${ }^{33}$.

Zgodnie z art. 72 ust. 1 zd. drugie konstytucji każdy ma prawo żądać od organów władzy publicznej ochrony dziecka przed przemocą, okrucieństwem, wyzyskiem i demoralizacją ${ }^{34}$. Z uwagi na fakt, że na rodzicach spoczywa obowiązek wychowania dziecka, prawo, o którym mowa w przytoczonym przepisie, przysługuje w pierwszej kolejności rodzicom. Ponieważ rodzice (lub inni członkowie rodziny) mogą być źródłem negatywnych zjawisk godzących w dobro dziecka, ustrojodawca przyznaje wspomniane prawo każdemu. Nie musi być to zatem opiekun prawny ani nawet opiekun faktyczny dziecka $^{35}$. Art. 72 ust. 1 zd. drugie konstytucji można uznać za klauzulę zabezpieczającą proces wychowania dziecka, za który odpowiedzialność spada w pierwszej kolejności na rodziców $w^{36}$.

${ }^{30}$ Confer M. Andrzejczak-Świątek, op. cit., s. 20.

31 W. Borysiak, komentarz do art. 72..., s. 1661 i tam przywołane orzecznictwo TK. „Przyjmuje się założenie, że dobro dziecka z reguły pozostaje w harmonii z interesem rodziców, natomiast w sytuacji, kiedy dochodzi do rozbieżności między tymi wartościami, interes rodziców powinien zejść na dalszy plan, jeśli w żaden sposób nie da się go pogodzić z interesem dziecka” (H. Babiuch, op. cit., s. 183).

32 Podobnie L. Garlicki, M. Derlatka, op. cit., s. 784.

33 P. Sarnecki, op. cit., s. 256-257.

34 Komentowany przepis konstytucji należy uznać za realizację zobowiązań wynikających z art. 19 Konwencji o prawach dziecka. Polska zgodnie z tym przepisem obowiązana jest podjąć właściwe kroki w dziedzinie ustawodawczej, administracyjnej, społecznej oraz wychowawczej dla ochrony dziecka przed wszelkimi formami przemocy fizycznej bądź psychicznej, krzywdy lub zaniedbania bądź złego traktowania lub wyzysku, w tym wykorzystywania w celach seksualnych, dzieci pozostających pod opieką rodziców, opiekuna prawnego lub innej osoby sprawującej opiekę nad dzieckiem.

${ }^{35}$ Confer uwagi w pkt 5 niniejszego opracowania zgłoszone na tle art. 72 ust. 3 konstytucji.

36 W. Borysiak, komentarz do art. 72..., s. 1650. 
Sytuacje, które uzasadniają interwencję władz publicznych na rzecz zapewnienia ochrony dziecku (przemoc, okrucieństwo, wyzysk i demoralizacja), stanowią granicę rodzicielskiej wolności wychowania dziecka zgodnie z własnymi przekonaniami (art. 48 ust. 1 zd. pierwsze konstytucji). Jako że chodzi o naruszenie konstytucyjnej zasady dobra dziecka, uzasadniają w szczególności ograniczenie lub pozbawienie praw rodzicielskich (art. 48 ust. 2 konstytucji) ${ }^{37}$.

$\mathrm{Z}$ istoty komentowanego prawa wynika, że osoba żądająca od organów władzy publicznej ochrony dziecka przed przemocą, okrucieństwem, wyzyskiem lub demoralizacją ma na względzie dobro dziecka. $Z$ tego też tytułu nie można mówić o naruszeniu prawa do ochrony życia rodzinnego czy — ujmując to inaczej — ,autonomii rodziny"38. Żądania ochrony dziecka przed przemocą, okrucieństwem, wyzyskiem i demoralizacją nie można uznać za ograniczenie prawa rodziców do wychowania dziecka zgodnie ze swoimi przekonaniami. Trudno zgodzić się z poglądem, że czuwanie nad procesem wychowania dziecka należy tylko do władz publicznych, a nie osób trzecich ${ }^{39}$. Dobro dziecka jest na tyle istotną wartością konstytucyjną, że dopuszcza możliwość interwencji osoby trzeciej w proces wychowania dziecka, jeżeli tylko uzna ona, że zachodzi konieczność zadbania o dobro dziecka ze względu na zagrażającą mu przemoc, okrucieństwo, wyzysk lub demoralizację. Żądanie ochrony dziecka przed przemocą, okrucieństwem, wyzyskiem lub demoralizacją może być realizowane w każdej sytuacji niezależnie od tego, czy dziecko wychowuje się w rodzinie (naturalnej). W sytuacji, w której dziecko nie jest wychowywane przez rodziców, żądanie takie staje się tym bardziej uzasadnione. Może być ono respektowane zwłaszcza wówczas, gdy realizowane są jakiekolwiek postacie pieczy zastępczej przewidziane przez ustawę z dnia 9 czerwca 2011 r. o wspieraniu rodziny i systemie pieczy zastępczej ${ }^{40}$. Jeżeli wobec dziecka została ustanowiona piecza zastępcza w postaci rodzinnej, żądanie ochrony dziecka przed przemocą, okrucieństwem, wyzyskiem lub demoralizacją odbywa się w warunkach zbliżonych do sytuacji dziecka w rodzinie naturalnej, z uwzględnieniem różnic w pozycji prawnej opiekunów dziecka. W zupełnie innych warunkach następuje natomiast realizacja żądania ochrony dziecka przed przemocą, okrucieństwem, wyzyskiem lub demoralizacją, jeżeli wobec dziecka została ustanowiona instytucjonalna piecza zastępcza w formie umieszczenia dziecka w placówce opiekuńczo-wychowawczej, regionalnej placówce opiekuńczo-terapeutycznej czy interwencyjnym ośrodku preadaptacyjnym. Wówczas w grę wchodzi odpowiedzialność osób kierujących tymi jednostkami i sprawujących opiekę nad dzieckiem z ramienia organu władzy publicznej.

${ }^{37}$ Idem, komentarz do art. 48, [w:] Konstytucja RP, t. I: Komentarz do art. 1-86, red. M. Safjan, L. Bosek, Warszawa 2016, s. 1203; wyrok TK z 11 października 2011 r., sygn. akt K 16/10, OTK ZU 2011/A8/80.

38 B. Banaszak, op. cit., s. 426.

${ }^{39}$ L. Garlicki, M. Derlatka, op. cit., s. 786.

${ }^{40}$ Tekst jedn. Dz.U. z 2019 r. poz. 1111, ze zm. 
Dobro dziecka stanowi sens i istotę realizacji prawa, o którym mowa w art. 72 ust. 1 zd. drugie konstytucji. Podmiot żądający ochrony praw dziecka nie musi zatem mieć w realizacji owego prawa własnego interesu prawnego. Stąd też zgodnie z tym artykułem można mówić o ustanowieniu przez ustrojodawcę skargi powszechnej (actio popularis $)^{41}$, realizowanej w imię dobra dziecka przez każdego, kto uzna potrzebę jej złożenia. W razie jej realizacji po stronie organu władzy publicznej, do którego złożono skargę, powstaje obowiązek wyjaśnienia sytuacji przez podjęcie odpowiednich kroków, skutecznie i rzeczywiście zmierzających do ochrony praw dziecka i udzielenia odpowiedzi na zgłoszone żądanie. Należy uznać, że dobro dziecka jest na tyle istotną wartością konstytucyjną, że usprawiedliwia każdą interwencję, nawet jeżeli w toku odpowiedniego postępowania miałaby się ona okazać bezzasadna i naruszała autonomię rodziny, w której dziecko się wychowuje.

Przypadki uzasadniające realizację prawa, o którym mowa w art. 72 ust. 1 zd. drugie konstytucji, tj. przemoc, okrucieństwo, wyzysk i demoralizacja, można określić jako najgroźniejsze przejawy patologii sytuacji dziecka ${ }^{42}$. W skrajnym przypadku żądanie od organów władzy publicznej ochrony dziecka przed przemocą, okrucieństwem, wyzyskiem lub demoralizacją może przybrać postać zawiadomienia o popełnieniu przestępstwa $^{43}$. Niemniej pojęcia zastosowane przez ustrojodawcę w art. 72 ust. 1 zd. drugie nie są tożsame z przepisami kodeksu karnego określającymi typy przestępstw. Dlatego też ochrona dziecka musi być zapewniona za pomocą szerszej gamy środków niż tylko karnoprawnych ${ }^{44}$.

Użyte przez ustrojodawcę terminy: ,przemoc”, „okrucieństwo”, „wyzysk” i „demoralizacja" mają charakter autonomiczny i nie powinny być interpretowane przez pryzmat aktów niższego rzędu ${ }^{45}$. Niemniej rozwiązania ustawowe mogą mieć walor subsydiarny przy ustaleniu ich znaczenia. Zwłaszcza przy interpretacji terminu ,przemoc” pomocniczo można stosować przepisy ustawy z dnia 29 lipca 2005 r. o przeciwdziałaniu przemocy $\mathrm{w}$ rodzinie ${ }^{46}$. Zgodnie $\mathrm{z}$ tą ustawą przemoc $\mathrm{w}$ rodzinie oznacza jednorazowe albo powtarzające się umyślne działanie lub zaniechanie naruszające prawa lub dobra osobiste

${ }^{41}$ W. Borysiak, komentarz do art. 72..., s. 1664; E.H. Morawska, Ochrona praw dziecka w świetle art. 72 Konstytucji. Uwagi na tle orzecznictwa Trybunatu Konstytucyjnego, „Kwartalnik Prawa Publicznego" 2007, nr 4, s. 140.

42 L. Garlicki, M. Derlatka, op. cit., s. 785.

${ }^{43} \mathrm{~W}$ art. 304 ustawy z dnia 6 czerwca 1997 r. - Kodeks postępowania karnego (tekst jedn. Dz.U. z 2018 r. poz. 1987, ze zm.) każdy, dowiedziawszy się o popełnieniu przestępstwa ściganego z urzędu, ma społeczny obowiązek zawiadomić o tym prokuratora lub policję. Ponieważ obowiązek ten nie ma charakteru prawnego, jego niezrealizowanie nie pociąga za sobą sankcji. Dlatego też uznaje się, że chodzi raczej o uprawnienie każdego do złożenia zawiadomienia o popełnieniu przestępstwa (vide S. Cora, Zawiadomienie o przestępstwie jako obowiązek i uprawnienie, „Państwo i Prawo” 2011, z. 6, s. 77 i n.). W przypadku potrzeby ochrony dziecka realizacja wzmiankowanego przepisu stanowi zatem realizację prawa określonego w art. 72 ust. 1 zd. drugie konstytucji.

44 B. Banaszak, op. cit., s. 428.

45 W. Borysiak, komentarz do art. $72 \ldots$, s. 1665.

46 Tekst jedn. Dz.U. z 2015 r. poz. 1390, ze zm. 
członków rodziny ${ }^{47}$, w szczególności narażające te osoby na niebezpieczeństwo utraty życia, zdrowia, naruszające ich godność, nietykalność cielesną, wolność (w tym seksualną), powodujące szkody na ich zdrowiu fizycznym lub psychicznym, a także wywohujące cierpienia i krzywdy moralne u osób dotkniętych przemocą ${ }^{48}$. Za przemoc wobec dziecka należy uznać również stosowanie kar cielesnych. Tego rodzaju kary są zabronione zarówno w konstytucji (art. 40), jak i kodeksie rodzinnym i opiekuńczym (art. 961) ${ }^{49}$. Przemoc wobec dziecka może w drastycznych sytuacjach przybrać postać przestępstwa znęcania się (art. 207 k.k.) ${ }^{50}$. Efektywność działań władz publicznych w sytuacji stwierdzenia, że dziecko padło ofiarą przemocy (w tym również przemocy domowej), należy oceniać z punktu widzenia realnych kroków wymierzonych w kierunku sprawcy przemocy, a nie ograniczenia się do oficjalnej reakcji (np. przez wysłanie patrolu do miejsca, w którym dziecko uległo przemocy) ${ }^{51}$.

Okrucieństwo ma wymiar zbliżony do przemocy. Próba wskazania różnic między przemocą a okrucieństwem prowadzi do konstatacji, że „okrucieństwo ukierunkowane będzie zazwyczaj bardziej na sferę psychiczną niż fizyczną dziecka”, co oznacza, że może przybrać w szczególności postać upokarzania czy drastycznego wyszydzania ${ }^{52}$. Wyzysk natomiast w rozumieniu art. 72 ust. 1 zd. drugie konstytucji należy w szczególności sprowadzić do pracy wykonywanej przez dziecko i osiągania przez dziecko dochodów z tej działalności. Ponieważ z art. 65 ust. 3 konstytucji wynika, że dziecko powyżej 16. roku życia może być zatrudniane na stałe, wyzysk należy odnosić również do tej kategorii dziecka ${ }^{53}$.

Demoralizacja oznacza zanegowanie i odrzucenie norm i wartości moralnych uznawanych przez ogół społeczeństwa, które może prowadzić do nieprzestrzegania norm prawnych. W skrajnej postaci zjawiska demoralizacji podlegają ochronie prawnokarnej, np. przestępstwo rozpijania małoletniego (art. 208 k.k.). Należy też wspomnieć o przestępstwach, których ofiarą może paść dziecko, jak naruszenie intymności seksualnej (art. 191a k.k.) oraz innych przestępstwach przeciwko wolności seksualnej i obyczajności (art. 197 i n. k.k.). Właściwe środki zapobiegania i zwalczania demo-

${ }^{47} \mathrm{~W}$ przypadku rzeczonej ustawy chodzi o osoby najbliższe w rozumieniu art. $115 \S 11$ ustawy z dnia 6 czerwca 1997 r. - Kodeks karny (tekst jedn. Dz.U. z 2018 r. poz. 1600, ze zm.), tj. małżonka, wstępnego, zstępnego, rodzeństwo, powinowatego w tej samej linii lub stopniu, osobę pozostającą w stosunku przysposobienia oraz jej małżonka, osobę pozostającą we wspólnym pożyciu, a także inną osobę wspólnie zamieszkującą lub gospodarującą.

48 Vide P. Kruszyński, K. Wlaźlak, Przeciwdziałanie przemocy $w$ rodzinie na tle porównawczym, „Prokuratura i Prawo” 2017, nr 5, s. 37 i n.

49 Vide R. Krajewski, Kontratyp karcenia małoletnich po wprowadzeniu prawnego zakazu stosowania wobec nich kar cielesnych, „Palestra” 2012, nr 1-2, s. 49 i n.

50 Vide A. Gliszczyński, Przestępstwo znęcania się a przemoc w rodzinie, ,Studia Prawnicze i Administracyjne" 2011, nr 1, s. 141 i n.

${ }^{51}$ Confer M. Drewicz, Glosa do wyroku Europejskiego Trybunatu Praw Człowieka z dnia 9 czerwca 2009 r. w sprawie Nahide Opuz przeciwko Turcji (skarga nr 33401/02), „Przegląd Sejmowy” 2010, nr 3(98), s. 169.

${ }_{52}$ W. Borysiak, komentarz do art. 72..., s. 1665.

53 Ibidem. 
ralizacji w stosunku do osób, które nie ukończyły 18 lat, przewiduje ustawa z dnia 26 października 1982 r. o postępowaniu w sprawach nieletnich ${ }^{54}$.

Językowa wykładnia art. 72 ust. 1 zd. drugie konstytucji przemawiałaby na rzecz tezy, że okoliczności konstytuujące prawo osoby trzeciej do ochrony dziecka zostały nakreślone w formie katalogu zamkniętego ${ }^{55}$. Pogląd taki byłby jednak sprzeczny z ratio legis komentowanego przepisu, a zwłaszcza zasadą dobra dziecka. Dlatego też należy uznać, że prawem żądania podjęcia przez organy władzy publicznej stosownych działań ochronnych wobec dziecka dysponuje każdy, kto stwierdzi, że w jego przekonaniu dobro dziecka zostaje naruszone lub zagrożone z punktu widzenia obowiązujących norm prawnych oraz innych norm społecznych (w tym moralnych, estetycznych, obyczajowych). Stąd wniosek, że interwencja władz publicznych na rzecz realizacji dobra dziecka może wystąpić również w innych sytuacjach niż określone w art. 72 ust. 1 zd. drugie $^{56}$. Ochrona dziecka, o której mowa w art. 72 ust. 1, powinna mieć charakter zarówno prewencyjny, jak i następczy. Na organach władzy publicznej spoczywa zatem obowiązek podejmowania działań mających nie dopuścić do sytuacji, w której dziecko mogłoby się stać ofiarą przemocy, okrucieństwa, wyzysku i demoralizacji. Jeżeli natomiast dojdzie już do takiej sytuacji, organy władzy publicznej są obowiązane minimalizować jej negatywne skutki ${ }^{57}$.

Organem szczególnie predysponowanym do rozpatrzenia skargi, o której mowa w art. 72 ust. 1 zd. drugie konstytucji, jest Rzecznik Praw Dziecka. Zgodnie z art. 3 ust. 3 ustawy z dnia 6 stycznia 2000 r. o Rzeczniku Praw Dziecka ${ }^{58}$ do zadań tego organu należy podejmowanie działań zmierzających do ochrony dziecka przed przemocą, okrucieństwem, wyzyskiem, demoralizacją, zaniedbaniem oraz innym złym traktowaniem. W ustawie powtórzone zostały sformułowania występujące w art. 72 ust. 1 zd. drugie (dodając „zaniedbanie” oraz ,inne złe traktowanie”) przewidziane w ustawie $\mathrm{z}$ własnej inicjatywy, biorąc pod uwagę w szczególności informacje pochodzące od obywateli lub ich organizacji, wskazujące na naruszanie praw lub dobra dziecka, powiadamia osobę lub organizację, która zgłosiła informację o naruszeniu praw lub dobra dziecka, o zajętym przez siebie stanowisku, a w przypadku podjęcia działania - o jego skutkach ${ }^{60}$.

54 Tekst jedn. Dz.U. z 2018 r., poz. 969.

55 Świadczy o tym zwłaszcza zastosowanie spójnika ,i” przy wyliczeniu okoliczności uzasadniających interwencję.

56 Vide E.H. Morawska, op. cit., s. 141-142.

57 B. Banaszak, op. cit., s. 428.

58 Tekst jedn. Dz.U. z 2017 r. poz. 922, ze zm.

59 Confer P.J. Jaros, Rzecznik Praw Dziecka w Polsce. Ukształtowanie Rzecznika Praw Dziecka w Polsce jako organu państwowego. Komentarz do ustawy o Rzeczniku Praw Dziecka, Warszawa 2013, s. 102-104.

${ }^{60}$ Vide A. Dombska, Pozycja ustrojowa oraz kompetencje Rzecznika Praw Dziecka, [w:] Dwadzieścia lat transformacji ustrojowej w Polsce, red. M. Zubik, Warszawa 2010, s. 488 i n.; L. Zacharko, B. Wartenberg-Kempka, Rzecznik Praw Dziecka w systemie pozasądowej ochrony praw dzieci, [w:] Pozasądowa ochrona praw $i$ wolności jednostki. Instytucje, standardy, efektywność, red. E. Wójcicka, Częstochowa 2014, s. 97 i n. 


\section{Prawo do opieki i pomocy władz publicznych w sytuacji pozbawienia opieki rodzicielskiej}

Prawo dziecka do opieki i pomocy ze strony władz publicznych ma szczególnie istotne znaczenie w sytuacji, w której dziecko zostaje pozbawione opieki rodzicielskiej ${ }^{61}$. Powody pozbawienia opieki rodzicielskiej mogą być różnej natury. Naturalną przyczyną jest śmierć rodziców. Wraz z zaistnieniem tego faktu prawnego ustaje władza rodzicielska. W takiej sytuacji sąd ustanawia opiekuna, który jako przedstawiciel dziecka władny jest składać w jego imieniu wiążące oświadczenia woli.

Artykuł 72 ust. 2 konstytucji zapewnia ochronę i pomoc władz publicznych każdemu dziecku faktycznie pozbawionemu opieki rodzicielskiej bez względu na formalnoprawny aspekt tego stanu rzeczy. Opieki rodzicielskiej, o której mowa w tym artykule, nie należy utożsamiać z prawami rodziców (art. 48 konstytucji) ani z pozakonstytucyjną instytucją władzy rodzicielskiej. Termin „opieka rodzicielska” należy interpretować w sposób autonomiczny, odpowiadający istocie regulacji przyjętej przez ustrojodawcę w komentowanym przepisie. Dlatego też należy uznać, że opieka rodzicielska w znaczeniu konstytucyjnym jest pojęciem szerszym niż władza rodzicielska. Trudno jednak zaprzeczyć, że o istocie opieki rodzicielskiej świadczy sprawowanie władzy rodzicielskiej, rozumianej jako kompleks wzajemnie ze sobą powiązanych praw i obowiązków rodziców w celu zapewnienia pieczy nad osobą i majątkiem dziecka ${ }^{62}$. O możliwości wykonywania władzy rodzicielskiej decyduje posiadanie pełnej zdolności do czynności prawnych. Jej brak po stronie jednego z rodziców powoduje, że władza rodzicielska wykonywana jest w pełni przez drugiego rodzica ${ }^{63}$. Jeżeli żaden z rodziców nie jest zdolny do wykonywania władzy rodzicielskiej, ustanawiana jest dla dziecka opieka (art. $94 \S 3$ k.r.o.).

Inną przyczyną ustania władzy rodzicielskiej niż śmierć rodziców jest orzeczenie sądu, który władny jest orzec o zmianie stanu cywilnego dziecka ${ }^{64}$, ubezwłasnowolnieniu rodziców oraz pozbawieniu władzy rodzicielskiej rodziców w przypadku niemożliwości jej wykonywania lub nienależytego wykonywania (art. 111 k.r.o.) ${ }^{65}$. Trwała niemożność wykonywania władzy rodzicielskiej zachodzi w przypadku faktycznego jej niewykonywania, zwłaszcza porzucenia dziecka (np. z powodu wyjazdu rodziców

${ }^{61}$ Zgodnie z art. 20 Konwencji o prawach dziecka, dziecko pozbawione czasowo lub na stale swojego środowiska rodzinnego ma prawo do specjalnej ochrony i opieki ze strony państwa. Na państwach stronach Konwencji ciąży obowiązek zapewnienia takiej ochrony i opieki; P. Wójcicka, Prawo dziecka do wychowania w rodzinie. Wybrane aspekty, [w:] Prawa dziecka w prawie międzynarodowym, red. E. Karska, Warszawa 2014, s. 25.

${ }^{62}$ H. Babiuch, op. cit., s. 182.

63 T. Smyczyński, Prawo rodzinne i opiekuńcze, Warszawa 2018, s. 257.

${ }^{64}$ Chodzi o orzeczenia sądowe w sprawie zaprzeczenia ojcostwa męża matki, zaprzeczenia macierzyństwa, stwierdzenia bezskuteczności uznania ojcostwa, uchylenia prawomocnego wyroku ustalającego ojcostwo, przysposobienia dziecka lub rozwiązania przysposobienia.

65 Vide I. Długoszewska, Przesłanki oraz skutki ograniczenia i pozbawienia władzy rodzicielskiej, Warszawa 2012, s. 228 i n. 
za granicę). Natomiast nienależyte wykonywanie władzy rodzicielskiej oznacza „nadużycie tej władzy ze szkodą dla dziecka bądź rażące zaniedbanie przez rodziców ich obowiązków"66. Ustanie władzy rodzicielskiej równoznaczne jest zazwyczaj z ustaniem opieki rodzicielskiej w znaczeniu art. 72 ust. 2 konstytucji. Przypadek pozbawienia opieki rodzicielskiej w rozumieniu tego artykułu występuje również w razie zawieszenia władzy rodzicielskiej przez sąd na podstawie art. 110 k.r.o., tj. w sytuacji zaistnienia przemijającej przeszkody w wykonywaniu władzy rodzicielskiej. Zawieszenie władzy rodzicielskiej jest równoznaczne z ustanowieniem przez sąd opieki nad dzieckiem. O pozbawieniu praw rodzicielskich w rozumieniu art. 72 ust. 2 konstytucji należy także mówić w przypadku ograniczenia przez sąd władzy rodzicielskiej, którą to instytucję interpretuje się z art. 109 § 2-4 k.r.o. ${ }^{67}$

W razie uprawomocnienia się wyroku rozwodowego sąd pozostawia władzę rodzicielską obojgu rodzicom, jeżeli złożą oni w sądzie pisemne porozumienie zawarte zgodnie z dobrem dziecka. Przedmiotem owego porozumienia jest określenie sposobu wykonywania władzy rodzicielskiej i utrzymywania przez rodziców kontaktów z dzieckiem. Jeżeli takie porozumienie nie zostanie osiągnięte, stosowną decyzję podejmuje sąd. Może on dokonać rozdzielenia atrybutów władzy rodzicielskiej między rodzica$\mathrm{mi}^{68}$. Jeśli jednak sąd nie pozbawi obojga rodziców władzy rodzicielskiej (a także jej nie zawiesi lub nie ograniczy), nie można zwykle mówić o pozbawieniu dziecka opieki rodzicielskiej w rozumieniu art. 72 ust. 2 konstytucji, ponieważ przynajmniej jedno z rodziców wykonuje pełnię władzy rodzicielskiej. Można co najwyżej mówić o obowiązku władz publicznych do wspierania rodziny niepełnej (art. 71 ust. 1 zd. drugie konstytucji).

Jak zaznaczono wcześniej, błędem interpretacyjnym byłoby jednak utożsamianie co do zasady - opieki rodzicielskiej (art. 72 ust. 2 konstytucji) z władzą rodzicielską (art. 92 i n. k.r.o.). Może zajść taka sytuacja, w której rodzice sprawują faktyczną opiekę nad dzieckiem, mimo że są pozbawieni władzy rodzicielskiej. Funkcjonuje wówczas instytucja opiekuna, niemniej z punktu widzenia zasady dobra dziecka — w razie realizacji prawa, o którym mowa w art. 72 ust. 2 - trudno byłoby ograniczyć aktywność władz publicznych do stwierdzenia, że sytuacja prawna dziecka jest uregulowana. W każdej sytuacji faktycznego (a nie tylko prawnego) pozbawienia opieki rodzicielskiej władze publiczne są zobowiązane z mocy art. 72 ust. 2 udzielić dziecku rzeczywistej i efektywnej opieki i pomocy. Może wreszcie wystąpić sytuacja, w której rodzicami dziecka są osoby poniżej 18. roku życia. Wówczas to sami rodzice jako osoby małoletnie są dziećmi w rozumieniu konstytucyjnym, zatem wymagają opieki i pomocy oraz mogą domagać się jej udzielenia od władz publicznych stosownie do art. 72 ust. 2.

Prawo dziecka pozbawionego opieki rodzicielskiej do opieki i pomocy władz publicznych ma charakter prawa podmiotowego ${ }^{69}$. Powstaje wówczas, gdy dziecko faktycznie

${ }^{66}$ T. Smyczyński, op. cit., s. 275-276.

67 Vide I. Długoszewska, op. cit., s. 140 i n.

${ }^{68}$ T. Smyczyński, op. cit., s. 280.

${ }^{69}$ W. Borysiak, komentarz do art. 72..., s. 1666. 
zostaje pozbawione opieki rodzicielskiej nie tylko w sensie prawnym, ale również w takim zakresie, jaki normalnie przyjmuje się w aktualnych stosunkach społeczno-obyczajowych. Może więc to być sytuacja, w której organ władzy publicznej nie podjął jeszcze żadnych działań w związku z pozbawieniem dziecka opieki rodzicielskiej ani nawet nie powziął wiadomości na ten temat. Tym bardziej nie można ograniczać prawa dziecka, o którym mowa w art. 72 ust. 2 konstytucji, do czasu, w którym uprawomocni się orzeczenie sądu w przedmiocie ograniczenia lub pozbawienia władzy rodzicielskiej bądź też gdy w jakikolwiek inny sposób wystąpi ograniczenie lub pozbawienie praw rodzicielskich w rozumieniu art. 48 ust. 2 konstytucji. Powstania po stronie dziecka prawa podmiotowego do opieki i pomocy ze strony władz publicznych nie można uzależniać też od jakichkolwiek innych okoliczności pozbawienia opieki rodzicielskiej, nawet jeżeli ma ono charakter tymczasowy (np. ze względu na długotrwały wyjazd rodziców za granicę). Jedynym przypadkiem, jak należy sądzić, w którym nie będzie zachodziła sytuacja pozbawienia opieki rodzicielskiej, będzie krótkotrwała i przemijająca nieobecność rodziców połączona z oddaniem dzieci pod opiekę innych odpowiedzialnych osób.

W art. 72 ust. 2 dwukrotnie została użyta formuła „opieki”. Z jednej strony ustrojodawca odnosi się do opieki rodzicielskiej, z drugiej zaś — w sytuacji jej pozbawienia - do opieki (i dodatkowo pomocy) ze strony władz publicznych. Wynika z tego, że ,opieka i pomoc” władz publicznych ma być na tyle efektywna, aby równoważyć brak opieki rodzicielskiej. Nie chodzi przy tym jedynie o wymiar socjalno-bytowy. Władze publiczne obowiązane są, aby zapewnić dziecku opiekę również w wymiarze psychologiczno-emocjonalnym związanym z brakiem opieki rodzicielskiej. Może chodzić w szczególności o zorganizowanie opieki w ramach rodziny zastępczej, nierozłączanie z rodzeństwem, oddanie dzieci pod opiekę krewnych lub znajomych itd. Chodzi zatem o cały system pieczy zastępczej, o którym traktują przepisy kodeksu rodzinnego i opiekuńczego (art. $112^{1}$ i n.) oraz ustawy o wspieraniu rodziny i systemie pieczy zastępczej (art. 34 i n.).

\section{Prawo dziecka do wysłuchania przez organy władzy publicznej oraz osoby odpowiedzialne}

Prawo dziecka do bycia wysłuchanym należy do jego najbardziej podstawowych praw. Nie jest uzależnione od posiadania przez nie jakiejkolwiek zdolności do czynności prawnych ${ }^{70}$. Dotyczy każdej procedury, w której ma być określona sytuacja prawna dziecka, ma zatem walor uniwersalny ${ }^{71}$. Obowiązek wysłuchania i uwzględniania w miarę możliwości zdania dziecka ma znaczenie zwłaszcza wówczas, gdy organy władzy publicznej lub osoby odpowiedzialne za dziecko „nie mają ugruntowanych przekonań w jakiejś sprawie i dzięki wyartykułowaniu przez dziecko jego poglądów uzyskują

${ }^{70}$ Confer ibidem, s. 1667.

71 Może dotyczyć w szczególności ustalenia kontaktów z rodzicami (przy ich rozwodzie), ale również każdej innej sytuacji, jak np. wyrażenia zgody na zabieg leczniczy. 
dodatkowe bodźce dla podjęcia decyzji" "72. Nie budzi wątpliwości, że obowiązek wysłuchania i uwzględniania w miarę możliwości zdania dziecka musi zakładać profesjonalne przygotowanie przedstawicieli władzy publicznej do realizacji tego zadania.

Prawo dziecka do wysłuchania i w miarę możliwości uwzględnienia jego zdania w toku ustalania praw dziecka spoczywa, oprócz władz publicznych, również na osobach odpowiedzialnych za dziecko. Osobami tymi są w pierwszej kolejności rodzice. Dlatego też do nich skierowana jest dyspozycja art. 72 ust. 3 konstytucji. Powstaje zatem pytanie, jak ma się komentowany przepis do art. 48 ust. 1 „Rodzice mają prawo do wychowania dzieci zgodnie $\mathrm{z}$ własnymi przekonaniami. Wychowanie to powinno uwzględniać stopień dojrzałości dziecka, a także wolność jego sumienia i wyznania oraz jego przekonania". Należy uznać, że uwzględnianie stopnia dojrzałości dziecka, wolności jego sumienia i wyznania oraz przekonań związane jest $\mathrm{z}$ wysłuchaniem dziecka oraz uwzględniania $w$ miarę możliwości jego zdania. Proces wychowania jest też ściśle związany z ustalaniem praw dziecka. W kontekście powyższego art. 72 ust. 3 ma walor lex specialis wobec art. 48 ust. 1 zd. drugie konstytucji ${ }^{73}$.

Osób odpowiedzialnych za dziecko nie należy jednak ograniczać do rodziców czy też opiekunów prawnych (w sytuacji ustania władzy rodzicielskiej). Krąg ten tworzą również opiekunowie faktyczni dziecka, jeżeli tylko daje się stwierdzić, że sprawują choćby nawet przejściową pieczę nad dzieckiem ${ }^{74}$. Grono osób odpowiedzialnych za dziecko obejmuje zatem ,wszystkie podmioty uprawnione bezpośrednio i pośrednio do decydowania o ustaleniu praw do dziecka" 75 .

Obowiązek wysłuchania i w miarę możliwości uwzględniania zdania dziecka nie musi oznaczać wszczęcia formalnej procedury mającej doprowadzić do zapoznania się ze stanowiskiem dziecka ${ }^{76}$. Tak przynajmniej należy odczytywać dyspozycję art. 72 ust. 3 konstytucji w stosunku do osób odpowiedzialnych za dziecko niebędących przedstawicielami organów władzy publicznej. W przypadku działań podejmowanych przez organy władzy publicznej sprawa przedstawia się nieco inaczej, ponieważ są one obowiązane do działania na podstawie i w granicach obowiązującego prawa (art. 5 konstytucji). Każdy tryb postępowania przed organem władzy publicznej powinien zatem znajdować swoje unormowanie prawne. Zawsze jednak nadrzędną wartością i celem działania organu władzy publicznej powinno być dobro dziecka.

$\mathrm{Z}$ unormowań art. 72 ust. 3 konstytucji wynika, że charakter bezwzględny ma prawo dziecka do wysłuchania ${ }^{77}$. Wysłuchanie dziecka i sformułowanie przez nie zdania na określony temat nie jest równoznaczne z obowiązkiem jego uwzględnienia czy to przez osobę odpowiedzialną za dziecko, czy też organ władzy publicznej. Podmioty te

72 B. Banaszak, op. cit., s. 429.

73 W. Borysiak, komentarz do art. 72..., s. 1658.

74 J. Ignatowicz, M. Nazar, Prawo rodzinne, Warszawa 2016, s. 93; B. Banaszak, op. cit., s. 429.

${ }^{75}$ W. Borysiak, komentarz do art. 72..., s. 1667; wyrok TK z 11 października 2011 r. ...

76 B. Banaszak, op. cit., s. 429.

77 Confer art. 12 ust. 2 Konwencji o prawach dziecka — prawo do wysłuchania ograniczone jest do dzieci zdolnych do kształtowania własnych poglądów. 
są obowiązane do uwzględnienia zdania dziecka „w miarę możliwości”. Zdanie dziecka ma być zatem uszanowane, lecz nie można z nim wiązać jakichkolwiek skutków prawnych. Nieuwzględnienie zdania dziecka nie może pociągać za sobą jakiejkolwiek sankcji ${ }^{78}$. Art. $95 \S 4$ k.r.o. nakłada na rodziców obowiązek wysłuchania dziecka w ważniejszych sprawach dotyczących jego osoby lub majątku, jeśli rozwój umysłowy dziecka, jego stan zdrowia i stopień dojrzałości na to pozwalają, jak również w miarę możliwości uwzględniania rozsądnych życzeń dziecka ${ }^{79}$. W określonych sytuacjach zdanie dziecka musi być jednak uwzględnione. Przede wszystkim należy zauważyć, że zgodnie z unormowaniami kodeksu cywilnego dziecko powyżej 13. roku życia, jeśli nie zostało całkowicie ubezwłasnowolnione, dysponuje ograniczoną zdolnością do czynności prawnych. Może zatem składać prawnie wiążące oświadczenia woli w granicach określonych przepisami kodeksu cywilnego ${ }^{80}$.

Szczególny wymiar ma obowiązek wysłuchania zdania dziecka przez sąd. W sprawach dotyczących małoletniego dziecka sąd powinien wysłuchać dziecko, jeżeli pozwala na to rozwój umysłowy dziecka, stan zdrowia i stopień dojrzałości (art. $216^{1} \S 1$ i art. $576 \S 2$ k.p.c. $)^{81}$. Należy też podkreślić, że zgodnie z art. 118 k.r.o. na przysposobienie wymagana jest zgoda przysposabianego, który ukończył 13 lat. Sąd ma ponadto obowiązek wysłuchania przysposabianego dziecka, które nie ukończyło 13. roku życia, lecz może pojąć znaczenie przysposobienia ${ }^{82}$. Podobnie ustawa o wspieraniu rodziny i systemie pieczy zastępczej określa zasadę wysłuchania dziecka umieszczonego w pieczy zastępczej przy dokonywaniu oceny jego sytuacji (art. 4a).

\section{Podsumowanie}

Konstytucja gwarantuje dziecku prawo do opieki i pomocy władz publicznych na podstawie art. $72 \mathrm{w}$ związku z innymi przepisami konstytucyjnymi, a zwłaszcza art. 18 (ochrona małżeństwa, rodziny, macierzyństwa, rodzicielstwa), art. 48 (prawa rodziców do wychowania dzieci) i art. 71 (prawo rodziny do pomocy ze strony państwa). Na podstawie tych przepisów konstruuje się zasadę dobra rodziny i wynikającą z niej logicznie zasadę dobra dziecka. Ta ostatnia zasada stanowi punkt odniesienia do szczegółowych

78 W. Borysiak, komentarz do art. 72..., s. 1668.

79 „Jeżeli rodzice dojdą do przekonania, że ich dziecko jest na takim etapie rozwoju psychofizycznego, że potrafi dojrzale podjąć decyzję o pewnych przejawach swojego życia, że nie ulega przejściowej modzie, mogą - nie narażając się na zarzut działania wbrew zasadom współżycia społecznego i zasadzie dobra dziecka - wyrazić zgodę na takie czy inne postępowanie małoletniego" (J. Haberko, Charakter prawny relacji rodzice - dorosłe dzieci w kontekście zobowiąań alimentacyjnych rodziców, „Ruch Prawniczy, Ekonomiczny i Socjologiczny" 2015, z. 4, s. 45).

80 Vide w szczególności art. 21 i 22 k.c.

${ }^{81}$ Ustawa z dnia 17 listopada 1964 r. — Kodeks postępowania cywilnego, tekst jedn. Dz.U. z 2018 r. poz. 1360 , ze zm.

${ }^{82}$ M. Świderska, Przemiany polskiego prawa rodzinnego $w$ ostatnim dziesięcioleciu $w$ świetle standardów międzynarodowych, „Studia Iuridica Toruniensia” 2002, nr 1, s. 98-99. 
przepisów konstytucyjnych określających prawa dziecka. Na konstytucyjne prawo dziecka do opieki i pomocy władz publicznych składają się trzy elementy: prawo do ochrony przed przemocą, okrucieństwem, wyzyskiem i demoralizacją, prawo do opieki i pomocy władz publicznych w sytuacji pozbawienia opieki rodzicielskiej oraz prawo do wysłuchania i formułowania swojego zdania przed organami władzy publicznej. Wynikają one expressis verbis $\mathrm{z}$ art. 72, choć ich znaczenie $\mathrm{w}$ konstytucyjnym systemie ochrony praw dziecka jest różne. Pierwsze dwa mają charakter materialny i odnoszą się do ekstremalnych sytuacji w życiu dziecka, w których nie może ono liczyć na pomoc i opiekę ze strony rodziców czy to z powodu zaniedbań w procesie wychowawczym, czy faktycznego ustania opieki rodzicielskiej. Prawo do wysłuchania ma zaś wymiar proceduralny i stanowi wyraz upodmiotowienia dziecka, któremu ustrojodawca umożliwia wyrażanie stanowiska w sprawach bezpośrednio go dotyczących. Nie ma natomiast w Polsce bezpośredniej podstawy konstytucyjnej, która dawałaby możliwość pozbawiania rodziców władzy rodzicielskiej z tytułu braku możliwości wychowania dziecka w odpowiednich warunkach materialnych. Wręcz przeciwnie, logika przepisów konstytucyjnych nakazuje udzielanie przez władze publiczne wszechstronnej pomocy na rzecz rodziny, aby w jak najpełniejszym stopniu mogła być zrealizowana konstytucyjna zasada dobra dziecka.

Z przeprowadzonej analizy wynika również pewna niespójność przepisów kodeksu rodzinnego i opiekuńczego oraz kodeksu cywilnego z przepisami konstytucji, szczególnie jeżeli chodzi o ujęcie istoty pojęcia „dziecka”. Zgodnie z przepisami konstytucji dzieckiem jest każda osoba, która nie ukończyła 18. roku życia. Przepisy kodeksowe upatrują natomiast istoty pojęcia „dziecka” w jego małoletniości i pozostawaniu pod władzą rodzicielską. W efekcie możliwa jest sytuacja, w której osoba poniżej 18. roku życia osiągnie pełnoletność, lecz nie traci statusu dziecka w rozumieniu przepisów konstytucji.

\section{Bibliografia}

\section{ŹRÓDŁA}

Konstytucja Rzeczypospolitej Polskiej z dnia 2 kwietnia 1997 r., Dz.U. nr 78, poz. 483, ze zm. Konwencja o prawach dziecka przyjęta przez Zgromadzenie Ogólne Narodów Zjednoczonych dnia 20 listopada 1989 r., Dz.U. z 1991 r. nr 120, poz. 526.

Ustawa z dnia 25 lutego 1964 r. — Kodeks rodzinny i opiekuńczy, tekst jedn. Dz.U. z 2017 r. poz. 682 , ze zm.

Ustawa z dnia 23 kwietnia 1964 r. — Kodeks cywilny, tekst jedn. Dz.U. z 2018 r. poz. 1025, ze zm.

Ustawa z dnia 17 listopada 1964 r. - Kodeks postępowania cywilnego, tekst jedn. Dz.U. z 2018 r. poz. 1360 , ze zm.

Ustawa z dnia 26 października 1982 r. o postępowaniu w sprawach nieletnich, tekst jedn. Dz.U. z 2018 r. poz. 969.

Ustawa z dnia 6 czerwca 1997 r. — Kodeks karny, tekst jedn. Dz.U. z 2018 r. poz. 1600, ze zm. 
Ustawa z dnia 6 czerwca 1997 r. - Kodeks postępowania karnego, tekst jedn. Dz.U. z 2018 r. poz. 1987 , ze zm.

Ustawa z dnia 6 stycznia 2000 r. o Rzeczniku Praw Dziecka, tekst jedn. Dz.U. z 2017 r. poz. 922 , ze zm.

Ustawa z dnia 29 lipca 2005 r. o przeciwdziałaniu przemocy w rodzinie, tekst jedn. Dz.U. z 2015 r. poz. 1390 , ze zm.

Ustawa z dnia 9 czerwca 2011 r. o wspieraniu rodziny i systemie pieczy zastępczej, tekst jedn. Dz.U. z 2019 r. poz. 1111, ze zm.

Wyrok Trybunału Konstytucyjnego z 28 kwietnia 2003 r., sygn. akt K 18/02, OTK 2003/4A/32. Wyrok Trybunału Konstytucyjnego z 11 października 2011 r., sygn. akt K 16/10, OTK 2011/ $8 \mathrm{~A} / 80$.

\section{PIŚMIENNICTWO}

Andrzejczak-Świątek M., Ochrona praw dziecka w sytuacjach nadzwyczajnych, Biuro Rzecznika Praw Dziecka, Warszawa 2016.

Babiuch H., Konstytucyjne prawa rodziców w zakresie wychowania dziecka, [w:] Realizacja $i$ ochrona konstytucyjnych wolności i praw jednostki $w$ polskim porzadku prawnym, red. M. Jabłoński, Wydział Prawa, Administracji i Ekonomii Uniwersytetu Wrocławskiego, Wrocław 2014.

Banaszak B., Konstytucja Rzeczypospolitej Polskiej. Komentarz, C.H. Beck, Warszawa 2012.

Borysiak W., komentarz do art. 48, [w:] Konstytucja RP, t. I: Komentarz do art. 1-86, red. M. Safjan, L. Bosek, C.H. Beck, Warszawa 2016.

Borysiak W., komentarz do art. 72, [w:] Konstytucja RP, t. I: Komentarz do art. 1-86, red. M. Safjan, L. Bosek, C.H. Beck, Warszawa 2016.

Bzdak H., Prawo dziecka do życia i godnego wychowania - uwarunkowania prawne, religijne i społeczne, SWA „Ottonianum”, Szczecin 2000.

Cora S., Zawiadomienie o przestępstwie jako obowiazek i uprawnienie, „Państwo i Prawo” 2011, z. 6.

Długoszewska I., Przesłanki oraz skutki ograniczenia i pozbawienia władzy rodzicielskiej, Lexis Nexis Polska, Warszawa 2012.

Dobrowolski M., Status prawny rodziny w świetle nowej Konstytucji Rzeczypospolitej Polskiej, „Przegląd Sejmowy” 1999, nr 4(33).

Domański M., Względne zakazy matżeńskie, Lex \& Wolters Kluwer business, Warszawa 2013.

Dombska A., Pozycja ustrojowa oraz kompetencje Rzecznika Praw Dziecka, [w:] Dwadzieścia lat transformacji ustrojowej w Polsce, red. M. Zubik, Wydawnictwo Sejmowe, Warszawa 2010.

Drewicz M., Glosa do wyroku Europejskiego Trybunału Praw Człowiekaz dnia 9 czerwca 2009 r. w sprawie Nahide Opuz przeciwko Turcji (skarga nr 33401/02), „Przegląd Sejmowy” 2010, nr 3(98).

Garlicki L., Derlatka M., komentarz do art. 72, [w:] Konstytucja Rzeczypospolitej Polskiej, t. II: Komentarz do art. 30-86, red. L. Garlicki, M. Zubik, Wydawnictwo Sejmowe, Warszawa 2016.

Gliszczyński A., Przestępstwo znęcania się a przemoc w rodzinie, „Studia Prawnicze i Administracyjne" 2011, nr 1.

Haberko J., Charakter prawny relacji rodzice — dorosłe dzieci w kontekście zobowiazań alimentacyjnych rodziców, „Ruch Prawniczy, Ekonomiczny i Socjologiczny” 2015, z. 4.

Ignatowicz J., Nazar M., Prawo rodzinne, Wolters Kluwer, Warszawa 2016.

Jaros P.J., Rzecznik Praw Dziecka w Polsce. Uksztattowanie Rzecznika Praw Dziecka w Polsce jako organu państwowego. Komentarz do ustawy o Rzeczniku Praw Dziecka, Biuro Rzecznika Praw Dziecka, Warszawa 2013. 
Krajewski R., Kontratyp karcenia małoletnich po wprowadzeniu prawnego zakazu stosowania wobec nich kar cielesnych, „Palestra” 2012, nr 1-2.

Kruszyński P., Wlaźlak K., Przeciwdziałanie przemocy w rodzinie na tle porównawczym, „Prokuratura i Prawo" 2017, nr 5.

Markowska-Gos E., Realizacja praw dziecka we wspótczesnej rodzinie - wybrane aspekty socjologiczno-prawne, [w:] Prawa dziecka. Wybrane aspekty, red. I. Marczykowska, E. Markowska-Gos, A. Solak, W. Walc, Wydawnictwo Uniwersytetu Rzeszowskiego, Rzeszów 2006.

Mączyński A., Konstytucyjne podstawy prawa rodzinnego, [w:] Państwo prawa i prawo karne. Księga jubileuszowa Profesora Andrzeja Zolla, t. I, red. P. Kardas, T. Sroka, W. Wróbel, Lex a Wolters Kluwer business, Warszawa 2012.

Morawska E.H., Ochrona praw dziecka w świetle art. 72 Konstytucji. Uwagi na tle orzecznictwa Trybunatu Konstytucyjnego, „Kwartalnik Prawa Publicznego” 2007, nr 4.

Ożóg M., Dobro dziecka, czyli poszanowanie jego podmiotowości prawnej w świetle wybranych przepisów prawa polskiego, [w:] Dobro dziecka. Perspektywa pedagogiczna i prawna, red. E. Włodek, Z. Solak, T. Gurdak, Akademia Ignatianum, Kraków 2017.

Sarnecki P., komentarz do art. 48, [w:] Konstytucja Rzeczypospolitej Polskiej, t. II: Komentarz do art. 30-86, red. L. Garlicki, M. Zubik, Wydawnictwo Sejmowe, Warszawa 2016.

Smyczyński T., Prawo rodzinne i opiekuńcze, C.H. Beck, Warszawa 2018.

Sokołowski M., Dobro dziecka w prawie rodzinnym Unii Europejskiej. Aspekt formalnoprawny, [w:] Prawa dziecka w prawie międzynarodowym, red. E. Karska, Wydawnictwo Uniwersytetu Kardynała Stefana Wyszyńskiego, Warszawa 2014.

Świderska M., Przemiany polskiego prawa rodzinnego $w$ ostatnim dziesięcioleciu $w$ świetle standardów międzynarodowych, „Studia Iuridica Toruniensia” 2002, nr 1.

Wójcicka P., Prawo dziecka do wychowania w rodzinie. Wybrane aspekty, [w:] Prawa dziecka w prawie międzynarodowym, red. E. Karska, Wydawnictwo Uniwersytetu Kardynała Stefana Wyszyńskiego, Warszawa 2014.

Zacharko L., Wartenberg-Kempka B., Dobro dziecka jako wartość najwyższa w prawie administracyjnym, [w:] Aksjologia prawa administracyjnego, t. 1, red. J. Zimmermann, Wolters Kluwer Polska, Warszawa 2017.

Zacharko L., Wartenberg-Kempka B., Rzecznik Praw Dziecka w systemie pozasadowej ochrony praw dzieci, [w:] Pozasądowa ochrona praw $i$ wolności jednostki. Instytucje, standardy, efektywność, red. E. Wójcicka, Akademia im. Jana Długosza w Częstochowie, Częstochowa 2014. 